\title{
Environmental law in the United Kingdom post Brexit
}

\author{
Richard Macrory ${ }^{1}$
}

Published online: 24 September 2018

(C) The Author(s) 2018

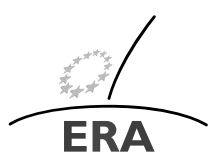

EUROPÄISCHE RECHTSAKADEMIE

ACADEMY OF EUROPEAN LAW ACADEMIE DE DROIT EUROPEEN ACCADEMIA DI DIRITTO EUROPEO
TRIER - TREYES - TREYIRI

\begin{abstract}
UK environmental law has been heavily influenced by EU membership, and Brexit presents both opportunities and challenges to its long-term development. In the immediate future the substance of much of existing EU environmental law will continue to have legal effect in the UK after Brexit under the Government's policy of 'roll-over'. But it has become increasingly clear that other features of the EU environmental architecture will need to be replicated after Brexit-notably the role of general environmental principles, and the European Commission's supervisory role in ensuring that environmental law is properly applied by government.
\end{abstract}

Keywords Brexit · Environmental principles $\cdot$ Roll-over $\cdot$ Enforcement

\section{The influence of EU environmental law in the UK}

At the time of writing, the outcome of the United Kingdom's BREXIT arrangements remains uncertain. Nevertheless, whatever the precise details of any agreement (or even lack of agreement) it is possible to predict at least some of the immediate impacts of Brexit on UK environmental law. In common with many EU Member States, national law and policy has been heavily influenced by the environmental legislation of the European Union over the past thirty years or so. EU membership has affected not simply the substance of UK environment law, but has brought profound changes

Richard Macrory is emeritus professor of environmental law at the Faculty of Laws, University College, London. In 2017 and 2018 he was co-chair of the UK Environmental Law Association's Brexit Task Force.

R. Macrory

r.macrory@ucl.ac.uk

1 Faculty of Laws, University College, London, UK 
to the style and character of its legislation. ${ }^{1}$ The UK has a long history of environmental law and regulation stretching back to the industrial revolution in the nineteenth century, but prior to membership of the EU, national environmental legislation was typically very detailed in procedural requirements (the need to obtain licenses for specified activities etc.) but frequently was silent as to policy goals which were left to government to determine. Similarly, the details of emissions standards and similar requirements were often left to the discretion of regulatory bodies to determine within the broad framework of environmental legislation, or in accordance with policy guidance set by government. The need to implement EU environmental legislation has substantially changed these long-standing characteristics of UK environmental law. Precise emission standards, detailed environmental quality objectives, and target obligations derived from EU law now permeate national law. A good example concerns drinking water standards. For many years, the standard in national legislation was simply one of supplying 'wholesome water' ${ }^{2}$ In practice, public bodies supplying water often used World Health Organization and international similar standards to flesh out this flexible legal phrase. But legislation since 1980, implementing the EC Drinking Water Directive, ${ }^{3}$ now contains a set of precise standards within the body of the law and reflecting those in the Directive. ${ }^{4}$ These characteristics are now so entrenched in the body of environmental law that, whatever changes take place in the longer term as a result of Brexit, it is unlikely that there will ever be a substantive return to the pre-EU style of legislation.

\section{The European Union (Withdrawal) Act 2018}

\subsection{The roll-over of EU environmental law}

Whatever form that Brexit takes, much of the substantive detail of environmental law will not change immediately. The Government policy has been that in the interests of regulatory certainty EU legislation should be 'rolled-over' as far as possible after Brexit. As the Government White Paper in 2017 stated, 'The Great Repeal Bill will ensure that the whole body of existing EU environmental law continues to have effect in UK law. This will provide businesses and stakeholders with maximum certainty as we leave the EU'. ${ }^{5}$ The legal mechanisms for doing so are provided in the European Union (Withdrawal) Act 2018 which introduces the concept of 'retained EU law'. Essentially any EU Regulation or EU decision addressed to the UK which was operative before the date of exit from the EU will continue to form part of domestic law. Similarly, 'EU derived domestic legislation' that implements EU Directives will continue in force. Furthermore, the principle of supremacy of EU law will continue

\footnotetext{
${ }^{1}$ Macrory [10].

${ }^{2} \mathrm{~S} 115$ Public Health Act 1936.

${ }^{3}$ Now Directive 98/83/EC of the Council of 3 November 1998 on the quality of water intended for human consumption [1998] OJ L 330/32.

${ }^{4}$ For current standards see Water Supply (Water Quality) Regulations 2016/614.

${ }^{5}$ Department for Exiting the European Union [2], p. 17.
} 
to apply to legislation made before the date of exit. ${ }^{6}$ EU environment Regulations made before exit day will therefore continue to override pre-existing national law if there is a conflict. But this principle of supremacy does not apply to legislation made after exit from the $\mathrm{EU}^{7}$ giving the freedom for Government and Parliament to change legislation in future, though subject to any constraints that may be contained in any agreement reached between the UK and the EU. As for the longer term future, the Government White Paper in 2017 noted that, after Brexit, 'We will then have the opportunity over time, to ensure our legislative framework is outcome driven and delivers on our overall commitment to improve the environment within a generation. $^{8}$

Directives themselves will have no independent legal status post Brexit since it is the implementing national legislation that continues to have effect. This could create problems where the national legislation has not correctly transposed a particular Directive - there will be no general duty on the courts to interpret such legislation in accordance with the Directive, and unless there has been a specific case prior exit date in either the Court of Justice of the European Union or the national courts on the issue, the 'direct effect' doctrine of directives will cease to apply: the European Union (Withdrawal) Act provides that rights arising under an EU Directive do not continue after Brexit unless 'of a kind recognised by the European Court or any court or tribunal in the United Kingdom in a case decided before exit day (whether or not as an essential part of the decision in the case). ${ }^{9}$

\subsection{Adjustment of roll-over EU law}

Many EU environmental regulations and national law implementing directives will therefore continue to have legal force immediately following the UK's exit from the EU. But there are clearly some examples where the substantive law is so intimately bound into EU institutional arrangements that simple roll-over is not possible unless specific agreements with the EU are made. Good examples are the EU emissions trading regime for greenhouse gases, ${ }^{10}$ and the EU Regulation of chemicals (REACH). ${ }^{11}$ A good deal of national environmental legislation now contains cross references to EU law. For example, the Environmental Permitting (England and Wales) Regulations 2016 defines a waste battery as having 'the meaning given in Article 3(7) of the Batteries Directive, but do not include any waste which is excluded from the scope

\footnotetext{
${ }^{6} \mathrm{~S} 5$ (2) European Union (Withdrawal) Act 2018.

${ }^{7}$ S 5(1) European Union (Withdrawal) Act 2018.

${ }^{8}$ Department for Exiting the European Union [3], p. 17.

${ }^{9} \mathrm{~S} 4(2)$ European Union (Withdrawal) Act 2018.

${ }^{10}$ Directive 2003/87/EC of the European Parliament and of the Council of 13 October 2003 establishing a scheme for greenhouse gas emission allowance trading within the Community and amending Council Directive 96/61/EC [2003] OJ L 275/32. In March 2018, the Minister for Energy and Clean Growth told Parliament that it was the UK Government's intention to stay within the EU Emissions Trading Scheme until the end of Phase 3 in 2020.

${ }^{11}$ Regulation 1907/2006/EC of the European Parliament and of the Council of 18 December 2006 concerning the Registration, Evaluation, Authorisation and Restriction of Chemicals (REACH) [2006] OJ L $396 / 1$.
} 
of that Directive by Article 2(2)'. ${ }^{12}$ Even though the Directive will have no independent legal force in the United Kingdom after Brexit, there seems no reason why such definitional references cannot continue-it would be similar to having a reference in legislation to a definition in an OECD or similar international document. In contrast, some EU Regulations and national legislation implementing containing references to the requirement to notify or consult the European Commission, and clearly these can no longer apply after Brexit and another body, such as the Secretary of State, will need to be substituted.

It is therefore clear that in order to ensure that retained EU law remains operable, there is a considerable task of detailed amendments that will be necessary, even if the core substantive obligations remain. In September 2017, the Secretary of State for Environment, Food and Rural Affairs told Parliamentarians that there were around 850 pieces of legislation within his Department's responsibility that would require amendment. ${ }^{13}$ Most of these concern animal and plant health and agriculture, with about a quarter in the environmental field. The issue will cover all areas of national law affected by EU legislation, and to allow for this scale of amendments to be made in the time-scales required and without overloading Parliament, the European Union (Withdrawal) Act 2018 has given government broad powers to make regulations considered 'appropriate to prevent, remedy or mitigate-(a) any failure of retained EU law to operate effectively, or (b) any other deficiency in retained EU law, arising from the withdrawal of the United Kingdom from the EU. ${ }^{14}$ The term 'Deficiencies' is further defined to include, inter alia, 'retained EU law that contains anything which has no practical application in relation to the United Kingdom or any part of it or is otherwise redundant or substantially redundant'. The scope of the discretion caused some concern during the passage of the Act through Parliament, but it is important to note that the legislation provides any such failures or deficiencies must arise out of Brexit. A government that was, for example, unhappy with the strict requirements of the Habitats Directive ${ }^{15}$ could not use these powers to amend the implementing regulations since they would not be 'deficient' in those terms.

There was a further concern in Parliament during the passage of the Act about the extent of these regulatory powers. Many of the references to EU law or institutions are contained in detailed national regulations, but primary legislation-Acts of Parliament-sometimes contains EU references, and will also require to be amended post-Brexit if the law is to remain operable. Generally, the legislative practice is that an Act of Parliament can only be amended by another Act of Parliament, but it was felt there would simply not be sufficient Parliamentary time to secure amendments in this way. Section 8 of the European Union (Withdrawal) Act therefore allows the regulations to amend Acts of Parliament as well as other regulations, a device known

\footnotetext{
${ }^{12}$ Environmental Permitting Regulations 2016, reg 2.

${ }^{13}$ Letter from the Secretary of State to Chair, House of Commons Select Committee on Environment, Food and Rural Affairs. This figure does to include EU environmental legislation that falls within the remit of other departments, and the total will therefore be higher.

${ }^{14} \mathrm{~S} 8$ (1)European Union (Withdrawal) Act 2018.

${ }^{15}$ Directive 92/43/EEC of the Council of 21 May 1992 on the conservation of natural habitats and of wild fauna and flora [1992] OJ L 206/7.
} 
as a 'Henry VIII' clause. ${ }^{16}$ There have been previous examples of such powers being given by legislation, but they have usually been fairly limited in their scope. Here the potential reach of such powers is much broader, giving rise to the political concern. However, a recent study of existing Acts of Parliament concerning the environment indicated that references to EU law or institutions was more limited that might have been thought (in contrast to environmental regulations) — out of twenty-nine environmental Acts, seventeen required no amendment, and in the remainder six changes were necessary while a further thirty would be advisable. ${ }^{17}$

\subsection{Decisions of the Court of Justice of the European Union}

The European Union (Withdrawal) Act 2018 also deals with the legal status of decisions of the CJEU. Decisions made by the CJEU after the UK's withdrawal from the EU will no longer bind the UK courts, nor will courts have any power to make references to the CJEU. In practice, the national courts are likely to have regard to post-Brexit decisions of the CJEU where, say, it is interpreting a term that appears in retained EU law, but they will not be bound to follow them. As for existing decisions of the court, the Act introduces a neat balance designed to maintain a degree of regulatory certainty but allowing some flexibility. The lower courts will continue to be bound by decisions made by the CJEU prior to Brexit, but the highest court, the Supreme Court, will have the discretion to depart from such decisions. But the Act states that it should only do so in line with its own practice of rarely departing from its own previous decisions. ${ }^{18}$ To take a recent example, in People over Wind and Sweetman $v$ Collite, ${ }^{19}$ the CJEU held that mitigation measures could not be taken into account when assessing whether a project was likely to have significant environmental effects under the Habitats Directive. This decision was contrary to previous decisions on the same point taken by the British High Court and Court of Appeal. Post Brexit, this decision will continue to bind the lower courts dealing with the national Habitats regulations, ${ }^{20}$ but if the issue ever reached the Supreme Court it could decide not the follow the ruling of the CJEU. Alternatively, the government post Brexit would have the power to amend the legislation should they wish, subject to the constraints that may be contained in any withdrawal agreement made between the EU and UK.

\footnotetext{
${ }^{16}$ Named after extensive powers to given to Henry VIII (1509-1547) under the Statute of Proclamations 1539.

${ }^{17}$ UK Environmental Law Association [14].

${ }^{18}$ In 1966 the Judicial Committee of the House of Lords, the predecessor to the Supreme Court, stressed the importance of binding precedent providing certainly in law but for the first time indicated that too rigid adherence to precedent could lead to injustice and that in future, while it would normally treat its previous decisions as binding, it would be prepared to depart from them 'when it appears right to do so': House of Lords Practice Statement (Judicial Precedent) [1966] 1 W.L.R. 1234. In 2010, the Supreme Court held that this Statement was still applicable to the Supreme Court: Austin $(F C) v$ London Borough of Southwark [2010] UKSC 28.

${ }^{19}$ Case C-323/17 Sweetman, EU:C:2018:244.

${ }^{20}$ Conservation of Habitats and Species Regulations 2017/1012.
} 


\section{Environmental principles}

The European Union (Withdrawal) Act provides that retained EU law is to be interpreted in accordance with 'retained general principles of EU law', provided it was recognised as a general principle by the CJEU before the date of departure from EU. However, the Act excludes any rights to claim damages under the rule in Frankovitch after exit, and the Charter of Fundamental Rights is expressly declared not to be part of domestic law once the UK leaves the EU. The environmental principles contain in Art. 191 TFEU are not considered to be general principles, and their role and status post Brexit has given rise to considerable political debate during the passage of the European Union (Withdrawal) Act in Parliament. The environmental principles are often mentioned in the preambles of Directives, but it is generally only the substantive provisions of directives, rather than the preambles, that are transposed into domestic law. This did not mean that the environmental principles would have been totally excluded from domestic law post Brexit. First, EU Regulations will continue to have force as retained EU law, and this appears to include their preambles. Secondly, decisions of the CJEU prior to Brexit and applying the environmental principles to the interpretation of EU environmental law will continue to bind the lower national courts in accordance with the provisions of the European Union (Withdrawal) Act described in Sect. 2.3 above.

General environmental principles have rarely formed part of UK national environmental law, and in the absence of a clear steer from the CJEU, it is rare for the EU environmental principles to be a determining factor in national judicial review cases challenging the legality of decisions taken by government or other public bodies. ${ }^{21}$ Nevertheless, there are examples of environmental principles such as the precautionary principle, being used by government inspectors determining appeals in areas such as water abstraction licences as a means of resolving complex and competing scientific evidence. ${ }^{22}$

The Government recognised that environmental principles could play a useful role post-Brexit and in May 2018 launched a consultation document on the possible role of environmental principles after Brexit. ${ }^{23}$ As the document stated, 'We believe it will be beneficial to underpin environmental regulation and policy-making with a clear set of principles. ${ }^{24}$ But the consultation document deliberately left open for discussion a number of broad questions - in particular what environmental principles should be included? Should they be expressed in legislation, or should they be contained in a Policy Statement explaining how they should be interpreted and applied? The consultation did not end until August 2018, but to a certain extent these open questions were overtaken by political events. During the passage of the European Union (Withdrawal) Act, the House of Lords passed an amendment, initiated by environmental NGOs, designed to incorporate the EU principles into UK law post-Brexit. The Government recognised that the issue now had considerable political support,

\footnotetext{
${ }^{21}$ Macrory and Thornton [9].

${ }^{22}$ Ibid., p. 910.

${ }^{23}$ Department for Environment Food and Rural Affairs [1].

${ }^{24}$ Ibid., para. 4.
} 
and proposed a counter-amendment which was passed by the House of Commons. ${ }^{25}$ This now provides that a set of environmental principles must be contained in legislation, but gives the Government rather more discretion in the legal role that they will play in future.

Section 16 of the European Union (Withdrawal) Act requires the Secretary of State to publish an environmental Bill within six months from the date the Act came into force (26 June 2018). This bill must contain a set of principles consisting of:

(a) the precautionary principle so far as relating to the environment,

(b) the principle of preventative action to avert environmental damage,

(c) the principle that environmental damage should as a priority be rectified at source,

(d) the polluter pays principle,

(e) the principle of sustainable development,

(f) the principle that environmental protection requirements must be integrated into the definition and implementation of policies and activities,

(g) public access to environmental information,

(h) public participation in environmental decision-making, and

(i) access to justice in relation to environmental matters.

Other principles could be added ${ }^{26}$ and many interest groups have suggested additional principles such as the non-regression principle.

As to the status of these principles, section 16 goes on to provide that the new Bill to be produced by Government must impose a duty on the Secretary of State to produce a policy statement in relation to the application and interpretation of these principles in connection with the making of policy by Government, and a duty to ensure that Government ministers 'must have regard to' these principles in circumstances provided for under the Bill. Clearly this still leaves considerable leeway for the Government, and it is likely that there will be pressure in Parliament during the passage of this new Bill during 2019 to strengthen these requirements. For example, many environmental NGOs argue that they should apply beyond central Government but to all public bodies making environmental decisions. Similarly, there will be pressure to strengthen the wording, 'have regard to', (which legally implies that while they must always be considered they can be ignored in any particular circumstance) to a duty to apply these principles in all decision-making.

\section{A new enforcement body}

One of the functions of the European Commission is to ensure that Member States properly implement their EU obligations, and Art. 258 of the TFEU gives the Commission a distinctive set of enforcement procerus which can eventually lead to action before the CJEU. These enforcement powers have been applied in all areas of EU law

\footnotetext{
${ }^{25}$ Where the House of Lords passes amendments to Government proposed legislation with which the House of Commons disagrees, the proposed legislation may go back and forth many times between the Lords and the Commons until agreement is reached-known as 'ping pong'. In this case, the House of Lords, while noting that the Commons amendment on environmental principles did not go as far as they wished, withdraw its own amendment.

${ }^{26} \mathrm{~S} 16(\mathrm{e})$ allows the inclusion in the Bill of 'other provisions as the Secretary of State thinks appropriate.'
} 
but the Commission has long been especially active in the environmental field-in 2015 the highest number of infringement proceedings concerned EU environmental law. ${ }^{27}$ There are reasons for this. In many fields of EU law such as employment, intellectual property and completion law, there are clear legal and economic interests who can be expected to ensure that their rights under EU law are properly protected. There is generally no equivalence of rights and private interests in the environment. Governments and public bodies in most jurisdictions have therefore been given distinctive responsibilities under national law for ensuring environmental protection, but it is often these bodies who are often faced with conflicting policy priorities and financial constraints, making the environment especially vulnerable. Environmental NGOs and other interest groups do of course play an important role in helping to ensure compliance with environmental law but cannot be expected to shoulder all the responsibilities for so doing.

Part of the Commission's supervisory role is to ensure that EU Directives are properly transposed into national law, but equally a breach of environmental law by a Member State in practice is considered a failure of its EU responsibilities. In this context, actions can be taken not just in respect of central government but any failing by an emanation of the state such as a local authority and a national environmental agency can also be considered a failing by the Member State concerned. In dealing with breaches in practice, the Commission does not have its own inspectorate within Members States, but has a developed a citizens' complaint procedure allowing anyone at no cost to alert it of possible breaches. This can then trigger the Commission to seek further information from the Member State concerned, and leading to possible infringement proceedings.

Much of the European Union (Withdrawal) Act 2018 is concerned with the 'rollover' of substantive EU law, but after Brexit, the European Commission will no longer have a supervisory role under Art. 258 TFEU. When this governance gap was pointed out to government by parliamentarians in $2017,{ }^{28}$ the initial response of the then Secretary of State for Environment Food and Rural Affairs was that existing judicial review procedures were adequate to ensure the legal accountability of government and other public bodies. It is true that the national courts have generally adopted a very liberal approach to questions of standing in environmental judicial reviews, with the result that almost any environmental organisation or concerned citizen will be permitted to bring a claim. But judicial reviews in the UK take place in the High Court and are resource intensive, and normally involve legal representation. Generally, the side that loses must pay the winning side's legal costs, and although, as a result of the Aarhus Convention, there are now statutory upper limits of the exposure to adverse costs orders, ${ }^{29}$ the financial resources and risks involved

\footnotetext{
${ }^{27}$ European Commission [4].

${ }^{28}$ See, for example, House of Lords [8]: 'The evidence we have heard strongly suggests that an effective and independent domestic enforcement mechanism will be necessary, in order to fill the vacuum left by the European Commission in ensuring the compliance of the Government and public authorities with environmental obligations. Such enforcement will need to be underpinned by effective judicial oversight, and we note the concerns of witnesses that existing domestic judicial review procedures may be inadequate and costly.' (para. 84).

${ }^{29}$ Under the Civil Procedure Rules, Part 45, in an Aarhus claim, a losing claimant may not generally be order to pay costs of the other side of more than $£ 5000$ (where the claimant is an individual) or $£ 10000$
} 
in judicial review remain considerable. Perhaps more importantly, it is clear that the European Commission attempts as far as possible to resolve infringement proceedings by negotiation and discussion - a very small proportion of cases ever reach the CJEU. Judicial review procedures, in contrast, are ill-suited to resolving issues in this way-once legal action is started it is rare for a case to settle before the court hearing, unless the weakness of one side's case becomes obvious.

In July 2017, a new Secretary of State was appointed, Michael Gove, one of the leading Brexiteers. He clearly wanted to make a distinctive mark with a vision of a powerful environmental policy post Brexit, and he immediately recognised that post Brexit judicial review was not sufficient in itself to hold government to account, but that some new national independent body would be needed. Other examples of similar bodies exist in the United Kingdom such as the Equality and Humans Rights Commission, established under the Equality Act 2006 with responsibility for the promotion and enforcement of equality and non-discrimination laws. Its powers include to carrying out of investigations, and the powers to serve compliance notices against both the private sector and governmental bodies. The 2018 Consultation Paper on environmental principles also discussed the need for a new national body to replace the supervisory role of the European Commission. But the idea had appeared to cause concern in other Departments and the Consultation Paper proposed the new body would have only powers to serve advisory notices on government rather than any further legal enforcement powers. Once again, during the parliamentary passage of the European (Union) Withdrawal Act, the House of Lords passed amendments to strengthen its powers. The compromise amendment accepted by government acknowledge that its powers must go beyond mere advice, and section 16 now requires the government to establish a new public authority with functions 'proportionate enforcement action (including legal proceedings if necessary) where the authority considers that a Minister of the Crown is not complying with environmental law.' 30

A number of important issues remain to be determined. First, as drafted, the provision only concerns breaches of environmental law by Ministers of the Crown (i.e. Central Government). It is clear that breaches by other public bodies should be within the jurisdiction of the new body. The simplest way of doing so would be to extend its powers and allow it to take enforcement action directly against local government and other public bodies as well as central government. An alternative model, which would more closely replicate the current enforcement role of the Commission, would allow the new body only to take action against central government but in respect of any breaches of law by any public body - an extended notion of responsibility which would be novel in conventional public law terms. But as the response of the UK Environmental Law Association put it, 'this approach ensures that Central Government cannot duck its responsibility to take steps to address the breach of environmental law by arguing that this is a matter for local government or some other public body. It would have to provide a convincing response to show that it is addressing the issue or default'. ${ }^{31}$ It is very unlikely that the new body will investigate and take action

(where the claimant is a company or organisation). A winning claimant may not normally be able to claim for than $£ 35000$ in legal costs.

${ }^{30} \mathrm{~S} 16(\mathrm{~d})$ European Union (Withdrawal) Act 2018.

${ }^{31}$ UK Environmental Law Association [13]. 
in respect of all environmental law breaches, but will be selective and strategic in its approach, only bringing action in the most serious cases. In those circumstances, it is not unreasonable that it should be central government that must sort out the problem, even if it was not the immediate cause of the breach.

The new body will undoubtedly try to resolve issues without the need for formal legal proceedings in much the way that the Commission does at present. But where proceedings are taken, another important issue to be determined is the power of the courts. Failure to comply with a judgment of the CJEU can lead to substantial financial penalties being imposed by the court under Art. 259 TFEU. In the environmental field, such penalties have been imposed on a number of Member States since 2000, and although the United Kingdom has yet to receive a penalty, the existence of such powers have undoubtedly focussed the minds of government. If one were to replicate the EU procedures in a national context, the new body would have power to serve a compliance notice. If this is confirmed by a court, and still not complied with by government, then the new body could seek a financial penalty from the court. But where central government was involved, some method of ring-fencing the penalty would be needed, otherwise it would simply be recycled with government. Others have argued that such explicit powers of penalty are not required, unless for totemic or political reasons. The failure of a government or other public body to comply with the judgments of a court in judicial review actions in any event is a contempt of court, and the courts have inherent powers to fine, sequester, in even imprison those responsible. In practice, it is very rare for a government or public body to fail to comply with a clear order of a court. Until the terms of the new Environment Bill are clear (probably end of 2018 or early 2019), the Government's view on these issues will not be known.

Finally, the proposed new body currently concerns England only. Environmental matters are now generally devolved to Scotland, Wales, and Northern Ireland, and in the absence of any specific agreement on these matters between the UK and the EU, central government does not have the legal powers to impose such a body on the devolved administrations. In an ideal world, the devolved governments would recognise the value of such a body having jurisdiction across the UK, or at the least the need to establish equivalent bodies in all the jurisdiction. But there continue to be tensions (especially between the UK government and Scotland) and it may well be that separate bodies are established in the different jurisdictions. ${ }^{32}$

\section{The UK and European environmental co-operation bodies post Brexit}

Over the last thirty years or so, a whole range of cooperation bodies and official networks have developed in Europe. Some, such as the European Environment Agency (EEA) and the European Chemical Agency, have been established under EU legislation. Others, such as the European Union Forum for Judge for the Environment

\footnotetext{
${ }^{32}$ See for example, Scottish Roundtable on Environment and Climate Change [11]. The report notes that, 'having a Scottish body with a thorough understanding of Scottish law, procedures and systems would be more focused on the issues that are most significant in a Scottish context. Scotland is of a scale at which we can envisage a separate body being justifiable and effective. However, we suggest that consideration be given to how arrangements might best work across the UK to allow collaboration, comparisons, efficient use of expertise and promotion of best practice.' (para. 5.16).
} 
and the European Network of Prosecutors for the Environment, have grown independently as officials and other bodies have found the value in sharing information and best practice. A recent report identified thirteen such bodies established under EU law, and five with their own constitution and rules of membership. ${ }^{33}$

There are a number of questions concerning the relationship of the UK with such bodies after Brexit. First, as a non-member-state, do the relevant rules permit the United Kingdom to remain a member? For example, non-EU countries can be a member of the European Environment Agency. ${ }^{34}$ There would be considerable benefits for the UK to remain a member of the EEA but under the present Regulation this would require an agreement to be reached between the EU and the UK, and the acceptance of the jurisdiction of the CJEU concerning contractual and other liabilities of the Agency. In contrast, the rules establishing the European IPPC Bureau allow membership of only Member States, and international organisations representing industries and non-governmental organisations. ${ }^{35}$ The current constitution of the European Union Forum for Judges for the Environment allows membership only of judges of the CJEU, the European Court of Human Rights, and judges of an EU or EFTA Member State.

The second question is whether it is in the interests of the UK to continue to interact with such bodies post Brexit. If it is, and current membership rules do not permit membership by non-EU countries, the UK could seek to secure amendment to the relevant rules, or some form of observer status through collateral agreements. The Government has yet to articulate a comprehensive strategy for dealing with the whole range of existing environmental co-operation bodies, but in its White Paper in July 2018 stated that its vision for an economic partnership with the EU 'would include participation by the UK in those EU agencies that provide authorisations for goods in highly regulated sectors-namely the European Chemicals Agency, the European Aviation Safety Agency, and the European Medicines Agency-accepting the rules of these agencies and contributing to their costs, under new arrangements that recognise the UK will not be a Member State'. 36

\section{International environmental law post Brexit}

The UK has ratified over forty international environmental treaties, and Government has several times stated that it remains committed to its international obligations post

\footnotetext{
${ }^{33}$ UK Environmental Law Association [12].

${ }^{34}$ Art. 19 of Regulation 2009/401 of the European Parliament and of the Council of 23 April 2009 on the European Environment Agency and the European Environment Information and Observation Network [2019] OJ L 126/13 provides that 'The Agency is open to countries which are not members of the Community but which share the concern of the Community and the Member States for the objectives of the Agency under agreements concluded between them and the Community following the procedure in Article 300 of the Treaty'.

${ }^{35}$ Decision 2011/C 146/03 of the Commission establishing a forum for the exchange of information pursuant to Article 13 of the Directive 2010/75/EU on industrial emissions [2011] OJ C 146/3 allows EEA members such as Norway to attend meetings of the forum.
}

${ }^{36}$ HM Government [4], p. 8. 
Brexit. But leaving the EU does raise some legal issues as to the extent of these obligations, because the EU has participated in many of these treaties. There are some such as the International Whaling Convention 1946 where the EU had no legal competence and the UK has ratified on its own. These obligations clearly continue after Brexit. On the other hand, there are areas, notably in fishing, where the EU has had exclusive competence to ratifying, binding the Member States in so doing. Here the UK will no longer be bound by these agreements unless it makes a conscious decision to ratify.

But the vast majority of international environmental conventions are so called mixed agreements where both the EU and Member States have ratified because their competence straddle the subject matter of the Convention in question. Here the legal position is not entirely certain. Some have argued that after Brexit these will no longer bind the UK unless, as with exclusive agreements, it decides to ratify in its own right. ${ }^{37}$ An alternative and probably more convincing analysis is that on Brexit the UK assumes all the competences formally held by the EU and is automatically bound by the full extent of these mixed international agreements. Simple notification to the relevant secretariat that it has assumed all the responsibilities is all that is required. The UK Government's view of the legal position of mixed agreements is not yet known.

But assuming that the UK does continue to be bound by all the international environmental agreements which it has ratified, this does not mean that the legal situation remains the same after Brexit. Many international agreements have been implemented by EU Directives and Regulations, and it is these instruments which have had direct legal force within the national system. Some of these have fleshed out requirements of the international convention or extended their ambit within the EU. A good example is the regulation on transfrontier shipments of waste ${ }^{38}$ implementing the Basel Convention. ${ }^{39}$ The Basel Convention is confined to hazardous waste whereas the EU regulation covers both hazardous and non-hazardous waste. In the immediate postBrexit period, the EU regulation will be 'rolled-over' into UK law, but in the future government could decides to amend the national law and confined itself solely to the requirements of the Convention in question.

Furthermore, the UK legal system has long operated a 'dualist system' in relation to international law, meaning that the national courts will not give direct legal force to the obligations in a convention unless they have been transposed into national law. In contrast to obligations under EU Directives, there is no constitutional or legal requirement on the UK to ensure that international environmental obligations are reflected in national law, and there are examples where mere statements of policy have been employed to reflect international obligations. It is true that in recent years the UK courts have frequently referred to international conventions to assist them in the interpretation of national law, but the fact remains that international law

\footnotetext{
${ }^{37}$ Van de Loo and Blocksman [5]; the authors argue that a protocol would be needed for each agreement agreed by the EU27 and other third country parties to the agreement.

${ }^{38}$ Regulation 1013/2006 of the European Parliament and of the Council of 14 June 2006 on shipments of waste [2006] OJ L 190/1.

${ }^{39}$ Basel Convention of 22 March 1989 on the control of transboundary movements of hazardous wastes and their disposal, United Nations, Treaty Series, vol. 1673, p. 57.
} 
does not have the same direct legal impact within the national context as does EU law. In many areas of the environment this has not been a significant issue since the international obligations have been operating, as it were, in the shadow of the more immediate implementing EU law. But in the future we can expect more attention to be given to international environmental in post Brexit UK. Aside from any provisions in any agreement reached with the EU, the international conventions which the UK has ratified will, post Brexit, form the main legal constraint on the freedom of the government to depart from current environmental norms. Whether this will embolden the national courts to give more weight to international law in purely national litigation remains to be seen. ${ }^{40}$

\section{Conclusions}

The Government's initial position on EU environmental law post Brexit has been that its requirements will initially be rolled over as far as possible into national law in order to provide legal stability and certainty. It is a technically complex task but achievably in most areas. Even decisions of the CJEU before Brexit will continue to bind the lower courts after the UK leaves the EU. 'Roll-over', however, is essentially concerned with the black letter of substantive law, and during the last two years it has become increasingly clear that there are significant aspects of the existing architecture of EU environmental law which are not dealt with by roll-over, and unless steps are taken would disappear after Brexit. Two notable examples are the role of EU environmental principles, and the supervisory role of the European Commission in ensuring that Member States comply with their EU obligations. To its credit, the Government has acknowledged the importance of replicating these features in national environmental post-Brexit, though the precise details as to how this will be done are not yet known. Similarly, the UK has been a participant in many European bodies and networks concerning the environment, both formal and less formal, and the extent to which it will continue to do so and on what basis remains a challenge. Finally, the UK has long been an active supporter of international environmental conventions, and remains committed to continue to do so in the future. The precise extent of its international obligations post Brexit where the EU has participated in such agreements still remains a little unclear. But it seems likely that post Brexit international environmental law will assume both greater political and legal significance.

On the political side, there is a degree of irony that one of the leading Brexiteers was appointed Secretary of State for Environment, Food and Rural Affairs in July 2017, and to the surprise of many environmental organisations has since pursued a bold and radical approach to environmental policy and law. A new 25 plan to improve the environment was published in January 2018 setting out ambitious proposals for

\footnotetext{
${ }^{40}$ In a recent decision of the Supreme Court concerning discrimination law, one of the judges suggested that where the UK had signed an international convention concerning human rights which had not been implemented into national law, the strict dualist approach should be ignored, and the Government be held bound by its international obligations by the national courts. He was in the minority, but this could be a pointer to the future. See $R$ (on the application of $S G$ and others) $v$ Secretary of State for Works and Pensions [2015] UKSC 16.
} 
the longer term post-Brexit. ${ }^{41}$ A month later, the Secretary of State launched a bold consultation paper to reform agricultural policy, ensuring that subsidies post Brexit went only for environmental and other land improvements. ${ }^{42}$ There is little doubt that is some areas such as agriculture and fisheries, a national government could implement more radical and environmentally sensitive policies quicker and more effectively than is possible within the EU. But this is dependent on national political leadership, and changes in government or even a move of ministers could equally lead to a lowering of environmental priorities, especially in the light of economic challenges post Brexit. The constraint of EU environmental law has to date provided a minimum set of legal standards to which all Member States are bound, and this legal bedrock will disappear after Brexit. Hence the importance of the terms of any agreement reached between the UK and the EU on Brexit concerning the maintenance of existing environmental standards. In the absence of such an agreement, international environmental law will assume far greater significance than has hitherto been the case. Brexit involves many uncharted legal waters. The extent to which it provides opportunities for the UK to enhance or degrade its environmental law remains to be seen.

Open Access This article is distributed under the terms of the Creative Commons Attribution 4.0 International License (http://creativecommons.org/licenses/by/4.0/), which permits unrestricted use, distribution, and reproduction in any medium, provided you give appropriate credit to the original author(s) and the source, provide a link to the Creative Commons license, and indicate if changes were made.

\section{References}

1. Department for Environment Food and Rural Affairs: Environmental Principles and Governance After the United Kingdom Leaves the European Union Consultation Document May 2018. DEFRA, London (2018)

2. Department for Environment, Food and Rural Affair: Health and Harmony; The Future for Food, Farming and the Environment in a Green Brexit. Cm 9577. DEFRA, London (2018)

3. Department for Exiting the European Union: Legislating for the United Kingdom's Withdrawal from the European Union. Cm 9446. HM Government, London (2017)

4. European Commission: Monitoring the application of European Union law. 2105 Annual Report COM (2016) 463 final

5. Van de Loo, G., Blocksman, S.: The Impact of Brexit on the EU's International Agreements. Centre for European Policy Studies, Brussels (2017)

6. HM Government: A Green Future: Our 25 Year Plan to Improve the Environment. UK Government, London (2018)

7. HM Government: The Future Relationship Between the United Kingdom and the European Union. Cm 9593. UK Government, London (2018)

8. House of Lords European Union Committee: Brexit: environment and climate change 12th report of session 2017-2017 14 Feb. 2017 HL Paper 109. UK Parliament, London (2017)

9. Macrory, R., Thornton, J.: Environmental principles—will they have a role after Brexit? J. Plann. Environ. Law 2017(9), 907-913 (2017)

10. Macrory, R., Law, E.: Shifting discretions and the new formalism. In: Lomas, O. (ed.) Frontiers of Environmental Law, pp. 8-23. Chancery Law, London (1991)

11. Scottish Roundtable on Environment and Climate Change: Environmental Governance in Scotland on the UK's Withdrawal from the EU. Scottish Government, Edinburgh (2018)

\footnotetext{
${ }^{41}$ HM Government [6].

${ }^{42}$ Department of Environment, Food and Rural Affairs [2].
} 
12. UK Environmental Law Association: Brexit and Environmental Law the UK and European Cooperation Bodies. UKELA, London (2017)

13. UK Environmental Law Association: UKELA's response to the environmental principles and governance consultation (July 2018). Available at https://www.ukela.org/content/page/6683/ UKELA EPG consultation reponse 31.7.18.pdf

14. UK Environmental Law Association: Brexit, Henry VIII Clauses and Environmental Law. UKELA, London (2017) 